\title{
Application of Hawear Customary Law in the Prevention of Pollution and Environmental Damage on the Sea Coast in Southeast Maluku Regency
}

\author{
La Ode Angga*, Barzah Latupono, Muchtar Anshary Hamid Labetubun, Sabri Fataruba \\ Faculty of Law, Pattimura University, Ambon 97233, Indonesia
}

Corresponding Author Email: laodeangga@yahoo.com

https://doi.org/10.18280/ijsdp.150519

Received: 23 March 2020

Accepted: 29 May 2020

\section{Keywords:}

application, Hawear customary law, pollution and damage prevention, environment

\begin{abstract}
This study aims to determine and analyze the application of hawear customary law in preventing pollution and environmental damage on the sea coast in Southeast Maluku Regency. This research is normative juridical research, that is research conducted on legal principles, in the sense of concrete legal values (norms) and legal systems. The approach used in research is the statute approach and conceptual approach. This study found the answer that the Hawear Customary Law in Southeast Maluku Regency according to the results of the study could be applied in preventing pollution and environmental damage on the sea coast in Southeast Maluku Regency by conducting customary deliberations (which were followed by Adat leaders (adat elders). The customary (adat elders) held a meeting and formulated the legal norms of Sasi (Hawear) Meti and Sasi Dusun Plant to apply to environmental protection, especially the prevention of pollution and environmental destruction on the coast of the sea, so that the coast along with its marine biota is usually enjoyed by the Indigenous Hawear people in Southeast Maluku Kabupaen from present and future generations by expanding the legal norms of Sasi.
\end{abstract}

\section{INTRODUCTION}

Local wisdom is the legacy of the ancestors of the Indonesian people in a unified value system in the form of local wisdom, religion, culture and customs. In the development of the community to adapt through its environment by developing wisdom in the form of knowledge or ideas combined with customary norms, cultural values and activities to manage the environment to meet their needs. If we look at the evolution of humans with nature in the past a harmonious relationship has been formed in which humans try to coexist peacefully with nature, in the view of humans that nature is large and sacred, it is necessary to live peacefully with nature so that no damage to nature will result in losses in humans themselves, in supporting this relationship humans create ethical acts and behave towards nature, almost most of the tribes in the country of Indonesia have rules that are called what is called local wisdom.

One of the local wisdoms of the people of Maluku, especially in Southeast Maluku, is Sasi Law, which has long been known in Maluku and has an important role in managing life, especially customary law communities. Sasi implies a prohibition on taking natural resources on land and at sea, which is based on several important and fundamental arguments. The principle that is the foundation for the existence of Sasi Law is actually the principle of sustainable management of natural resources. Wisdom thinking that developed locally is also based on the economic aspects of the people of the country and villages and villages, which are on small islands.

Indigenous peoples who live on small islands, the number is quite a lot and when compared with available natural resources. So it can be said that it is not enough to meet the basic needs of indigenous peoples, for a certain period of time. Therefore the thought was born to make a law that could regulate and organize all the potential of these natural resources so that they could be used wisely.

Natural resources on land in question for example, young coconut, pineapple, durian, langsat, sago leaves, nayang or palm leaves, natural resources in the sea in question such as fish, marine bioata, coral reefs, beach sand, rocks, and so on. Facts that occur in the Kei Islands of Southeast Maluku, Sasi is not only related to natural resources, but has been expanded to include rules relating to humans and other objects. Some examples that can be put forward include; Sasi is applied to forbid crossing the bridge and bridge, Sasi certain buildings that are considered problematic so it should not be used. Sasi is also applied to protect girls, so they are not taken away by male girlfriends (eloping) and so on. So actually the law of Sasi contains a deep and broad meaning, so that if it is lived and applied properly, as part of customary law instruments, the people of Maluku, then there will certainly be benefits for the life of the community in general.

The problems faced by the Indigenous Hawear people in the management of natural resources and the environment on the Coastal Coast, especially coastal areas, marine and small islands of Southeast Maluku Regency are mostly renewable natural resources that are very vulnerable to damage due to uncontrolled activities.

The main theme of this study is the Application of the Hawear Customary Law in the Prevention of Pollution and Environmental Damage on the Sea Coast in Southeast Maluku Regency. Based on literature searches in several articles including: research written by Netty Dahlan Ua, [1] with the 
title "Study of Environmental Damage Due to Human Activities in Coral Reef Ecosystems Case Study: Ngurbiot Ohoi Beach, Kei Kecil District, Southeast Maluku Regency, Maluku Islands Province.

The results of the study were the damage to coral reef ecosystems in Ohoi Ngurbloat, Kei Kecil Subdistrict, Southeast Maluku Regency. this is caused by anthropogenic (human activities) and non-anthropogenic (ecological changes, Ngurbloat Beach based on criteria of abundance index values, and diversity indices expressed in damaged to moderate natural factors), including: fishing using fish bombs, arrows. nets and traps. Intake of coral for building materials and aquarium decoration and wall decoration. Public perception about the condition of coral reefs in Ngurbloat Beach waters is influenced by the level of education and poverty. Research conducted by Netty Dahlan Ua [1] with the title "Study of Environmental Damage Due to Human Activities in Coral Reef Ecosystems Case Study: Ngurbiot Ohoi Beach, Kei Kecil Subdistrict, Southeast Maluku Regency, Maluku Islands Province is different from this research. This research focuses on applying sasi law in preventing pollution and destruction of natural resources and the environment in Southeast Maluku Regency.

The second research is a study conducted by Zulfikar Judge and Marissa Nurizka [2] with the title Role of Sasi Sea Indigenous Law in Protecting Environmental Sustainability in Eti Village, West Seram District, West Seram District, the results of this study are legal actions taken against legal violations Indigenous Sasi is sanctioned. Sanctions given in the village of Eti, West Seram sub-district, West Seram district in the form of sanctions from the village government, ancestors, and from God. This is because the eternal village has two forms of Sasi namely: Sasi Negeri and Sasi Church. Proof of these sanctions in the form of a roundabout around the village and fines for violations is different from this research which focuses on the application of the law in preventing pollution and destruction of natural resources and the environment in the Southeast Maluku District.

From the above background, of the course the author wants to expand the application of Sasi (Hawear) legal norms to the people of the coastal, marine and small islands of the Southeast Maluku Regency, which caused damage to the coral reef ecosystem in Ohoi Ngurbloat, Kei Kecil District, Southeast Maluku Regency. due to human activities and ecological changes, Ngurbloat Beach is based on the criteria of abundance index values, and the diversity index is stated in damaged to moderate natural factors. The focus of this research is the destruction of natural resources and the environment that occurs due to human ula in coastal areas, the sea and small islands in Southeast Maluku Regency which caused damage to the coral reef ecosystem in Ohoi Ngurbloat, Kei Kecil District, Southeast Maluku Regency.

From the focus of the above research, the formulation of the problem that will be examined and analyzed in the study is: How can the application of the Law of Sasi (Hawear) be applied in preventing pollution and environmental damage around the sea coast in Southeast Maluku Regency? The purpose of this study is to find out and analyze the application of the Law of Sasi (Hawear) which can be applied in preventing pollution and environmental damage around the sea coast in Southeast Maluku Regency.

\section{LITERATURE REVIEW}

\subsection{Theoretical framework}

To answer and at the same time a knife analysis of the formulation of the problem in this study, researchers used three (3) theories, namely: (1) Theory of Legal Effectiveness, (2) Theory of Norms and (3) Theory of Rule of Law.

\subsubsection{Legal effectiveness theory}

To maintain the effectiveness of the formulation of legal norms in this study, researchers used the theory of legal effectiveness proposed by Soerjono Soekanto. The theory of legal effectiveness according to Soerjono Soekanto, is that the effectiveness of a law is determined by five (5) factors, namely [3]:

(1) The legal factor itself (the law).

(2) Law enforcement factors, namely the parties who form or apply the law.

(3) Factors of facilities or facilities that support law enforcement.

(4) Community factors, namely the environment

(5) where the law applies or applies.

(6) Cultural factors, namely as the work, creation and taste based on human initiative in the association of life.

These five factors are interrelated with each other, because they are the essence of law enforcement, and are also a benchmark of the effectiveness of law enforcement [4]. Effectiveness can be interpreted as a process of achieving a predetermined goal. A business or activity can be said to be effective if the business or activity has achieved its objectives. If the intended purpose is an agency's goal, the process of achieving that goal is a success in carrying out the program or activity according to the authority, duties and functions of that agency. As for when we look at effectiveness in the field of law, Ali [5] argues that when we want to know the extent of the effectiveness of the law, then we must first be able to measure "the extent to which the rule of law is obeyed or not obeyed". Furthermore, Ali [5] stated that:

In general, many factors that influence the effectiveness of a law are the professional and optimal implementation of the roles, authorities and functions of law enforcers, both in explaining the tasks assigned to themselves and in enforcing these laws.

The five factors above are closely related, because they are the essence of law enforcement, are also a benchmark of the effectiveness of law enforcement [6]. In the first element, which determines whether the written law can function properly or not is dependent on the rule of law itself. According to Soerjono Soekanto [7], measures of effectiveness in the first element are:

(1) Existing regulations regarding certain areas of life are quite systematic.

(2) Existing regulations regarding certain areas of life are quite synchronous, hierarchically and horizontally there is no contradiction.

(3) Qualitatively and quantitatively the regulations governing certain areas of life are sufficient.

\subsubsection{Theory of norms}

The second theory (2), namely the theory of norm levels, the theory of norm levels in this study will be used to analyze issues related to the Norm Sasi Formulation which expand its meaning in preventing and polluting and damaging the field of 
natural resource management and the Environment on the Sea Coast in particular Coastal areas, the sea and small islands in Southeast Maluku Regency. Norm Level Theory was put forward by Hans Kelsen in his book Pure Theory of Law which was translated into Indonesian into Pure Legal Theory [8].

In line with the norm level theory, in research with a statute approach and conceptual approach must also understand the important principle of le superiori derogate legi inferiori. According to this principle, if there is a conflict between the statutory regulations which are inferior to the higher order, then the statutory regulations with the lower composition must be set aside [9]. This principle then gives birth to theories and research called the synchronization level of legislation that is vertical, in addition it is also known as the synchronization level or the suitability of legislation that is equal that regulates the same field or horizontal synchronization level of legislation [7].

Hans Kelsen discusses the validity of legal norms by describing it as a chain of validity that ends in the state constitution. If you ask why the constitution is valid, it might be able to refer to the old constitution. Eventually several constitutions were reached up to the first constitution adopted by an individual or some kind of assembly. The validity of the first constitution is the final presupposition, the final postulate, on which the validity of all norms in the rule of law depends. The document which constitutes the first constitution is actually a binding norm, only in the condition that the basic norm is presupposed as valid. This presupposition is called transcendental logical presupposition [7].

All legal norms belong to the same legal system because their validity can be traced back, directly or indirectly, to the first constitution. That the first constitution is a binding legal norm is something that is prepositioned, and the formulation of the preposition is the basic norms and rules of this law. The last sentence clearly shows two things, namely the basic norm and the preposition of its validity as the first constitution. Basic norms are not made in procedure by law-making organs. This norm is valid not because it is made by means of legal action, but is valid because it is presupposed to be valid, and presupposed is valid because without this presupposition no human action can be interpreted as law, specifically the norm of lawmakers [10].

Related to the substance of basic norms, Hans Kalsen distinguishes two types of norms or norm systems. Both are static norm systems (the static system of norm) and dynamic norm systems (the dynamic system of norm). Static norm system is a system that sees a norm in terms of the content or material content of the norm itself. The contents show that the proven quality directly guarantees its validity. Meanwhile, a dynamic norm system is a system that sees a norm whose formation is in accordance with procedures determined by the constitution. In other words, norms in the perspective of dynamic norm systems are norms that are born by the authorities to form these norms, which of course are derived from higher norms. The authority is a delegation. Norms that form authority are delegated from one authority to another. The first authority is the higher authority, the second authority is the lower authority.

It seems that the concept of the dynamic norm system constructed by Hans Kalsen above shows that the state organs having the authority to form laws can be traced to their validity through a hierarchical institutional relationship. This concept can be understood as a consequence of the character formation of hierarchical legal norms. The hierarchy according to the perspective of a dynamic norm system is of course adapted to the institutional structure or state administration adopted by a country which is regulated in its constitution [11].

\subsubsection{Legal Kaida theory}

Next the third theory (3) in this study is the theory of Kaida Hukum. According to researchers to support the theory of the effectiveness of law and the Norms stated above must be supported by the theory of law Kaida. The Rule Theory is divided into three types which are formulated as follows [12]:

(1) The rule of law applies juridically, if the determination is based on a rule of a higher level or is formed on a predetermined basis.

(2) The rule of law applies sociologically, if the rule is effective. That is, the rules referred to may be enforced by the authorities even though they are not accepted by the citizens (the theory of power) or the rules apply because of the recognition of the community.

(3) The rule of law applies philosophically, which is in accordance with the ideals of the law as the highest positive value.

If examined in depth, so that the effectiveness of law in society is truly functioning, each rule of law must meet the three types of elements above, for the following reasons [13]:

(1) if the rule of law only applies legally, there is a possibility that the rule is a dead rule;

(2) if it only applies sociologically in the sense of a theory of power, then that rule becomes a coercive rule;

(3) if it only applies philosophically, it is likely that the rule is only the law aspired (Ius constituendum).

\subsection{Conceptual framework}

In this research, besides using three (3) legal theories as stated above, this research also uses several conceptual foundations, namely:

\subsubsection{Custom and customary law}

Etymologically, in this case custom comes from Arabic which means habit, so etymologically custom can be defined as an act that is done repeatedly and then becomes a habit that is fixed and respected by people, then the habit becomes custom. Adat is a habit that grows and is formed from a community or region that is considered to have nails and is upheld and obeyed by supporting communities [14].

Understanding Adat is a rule, habits that grow and are formed from a community or region that is considered to have value and is upheld and adhered to by its supporting community. Adat is a normative custom and is validated by the community, so even though Adat does not keep repeating, at certain times it will continue over and over [15].

Customs are social habits that have been around for a long time in society with the intention of regulating order. There are also those who bind norms and behavior in the community, so that in doing an action they will think of the impact of the results or the set of behaviors that have the highest position because they are eternal and very strongly integrated to the community that owns them.

Customs is a collection of behavior that has the highest position because it is eternal and integrated very strongly to the people who have it [15]:

(1) Customs are eternal and hereditary behaviors of other generations of generations as inheritance so that they are 
strongly integrated with patterns of community behavior [16].

(2) Customs are cultural behaviors and rules that have been tried to be applied in the community.

(3) Customs are a characteristic of an area that has been adhered to long ago in the people who did it.

(4) Customs are a set of social rules that have long existed and have become a habit (tradition) in society.

Custom or habit can be interpreted as follows:

"Seseoarang's behavior is continuously carried out in a certain way and followed by outside communities for a long time" [17].

Thus the elements of the creation of Adat are:

(1) The existence of a person's behavior

(2) Performed continuously

(3) There is a time dimension.

(4) Followed by other people / the community.

Understanding the customs and attitudes related to the attitude and behavior of someone who was followed by another person in a process that is long enough, this shows the breadth of understanding of these customs. Each society or nation and state has its own customs, which one with the other is certainly not the same. Customs can reflect the soul of a community or nation and are a personality of a community or nation. The level of civilization, the modern way of life of a person cannot eliminate the behavior or customs that live and take root in society.

Adat always adapts itself to the conditions and progress of the times, so that Adat remains eternal, because Adat always adapts to the progress of society and the will of the times. Customs that live in the community are closely related to the traditions of the people and this is the main source of customary law.

According to Kusumadi Pudjosewojo, said that Adat is the behavior that the community adheres to. These customs are thick and some are thin and always thicken and thin out. The rules of behavior in this society are customary rules and not legal rules.

To get an idea of what is meant by customary law, it is necessary to examine a number of opinions as follows [18]:

(1) Mr. B. Terhaar Bzn

Customary law is the entire regulation that is incarnated in the decisions of customary leaders and applies spontaneously in the community. Terhaar is well-known for the "Decision" theory which means that to see whether something is a customary law it is customary law, it is necessary to look at the attitudes of the rulers of the legal community towards violators of customs and regulations. If the authorities impose sentences on violators, the customs are customary law.

(2) Mr. Cornelis van Vollen Hoven

Customary law is the overall rules of community behavior that apply and have sanctions and have not been codified.

(3) Sukanto

Customary law is a complex of customs that are generally not bible, not codified and are coercive, have sanctions so have legal consequences.

(4) Hazairin

Customary law is a precipice of decency in society that is the principle of morality whose truth has received general recognition in the community.

\subsubsection{Environment}

Understanding the environment is all objects, power, and conditions contained in a place or space where humans and living things are and can affect their lives. The environment, often referred to as the environment is a term that can include all living and non-living things in nature that are on earth or 19 parts of the earth, which function naturally without excessive human intervention [19].

Juridically, the understanding of the environment is regulated in Article 1 Paragraph (1) of Law Number 32 Year 2009 Regarding Environmental Protection and Management reads as follows [20]:

"The environment is a unity of space with all objects, power, conditions, and living things, including humans and their behavior, which affect nature itself, the continuity of life and the well-being of humans and other living things.

\subsubsection{Environmental law}

Many legal experts have conveyed the definition of environmental law. Of the many, not all of our legal experts' opinions are written in this article, only a few [21].

(1) Siti Sundari Rangkuti

According to this legal expert, the understanding of environmental law is a value. Where the values are moderate or have been applied to apply also in the future in the use and maintenance of the environment. This environmental law is commonly referred to as environmental governance law.

(2) Drupstee

Understanding environmental law according to Drupsteen: Environmental Law (Millieu recht) is a law relating to the natural environment (Naturalijk milleu) in the broadest sense. The scope is related to and determined by the scope of environmental management. Considering that environmental management is mainly carried out by the Government, the Environmental Law mostly consists of Government Law (bestuursrecht).

\section{(3) Danusaputro}

The opinion of the third legal expert states that environmental law is the law that underlies the implementation of protection and management as well as environmental resilience improvement. He is the one who distinguishes between modern environmental laws which are oriented to the environment or environment oriented law and classical environmental laws which are oriented towards the use of the environment or use-original.

(4) Gatot P. Soemartono

Gatot P. Soemartono stated that the definition of law is the whole regulation about human behavior that contains what should be done or not done in social life, the implementation of these regulations can be forced with a sanction by the authorities. From the description above regarding the definition of law, so the Definition of Environmental Law is the overall regulations governing people's behavior about what should be done to the environment, the implementation of these regulations can be imposed with a sanction by the authorities.

\section{RESEARCH METHOD}

This research is normative juridical research, that is research conducted on legal principles, in the sense of concrete legal values (norms) and legal systems [22]. The approach used in research [10] is the statute approach. and conceptual approach [9]. 


\section{RESULTS AND DISCUSSION}

\subsection{Understanding Sasi (Hawear)}

The term sasi is derived from Hawear Balwirin which is contained in Article 7 of the Larwul Ngabal customary law which is the highest customary law in the Kei islands, this Hawear Balwirin regulates the ownership rights of a person made by his ancestors who must be followed in the daily life of. this community which is famous for its that someone's property remains his, and ours remain ours which contains recognition and respect, awareness, nobleness, border restrictions, human rights and the law not to take the rights of others and to protect private ownership and general ownership, it is realized in the form of Sasi.

The relationship between community trust and understanding of the ecological conditions of indigenous peoples' environment can be demonstrated through their knowledge that has been preserved for generations, Indonesia's environmental conditions produce ecosystem diversity and natural resources give birth to Indonesian people that are closely related to natural conditions in carrying out various activities to uphold their survival.

Sasi is marked by the installation of young coconut leaves (yellow palm) that is cross-woven into the palm fronds and then tied to a piece of wood that is stuck to the ground near objects or items to be worn. This means it is forbidden for anyone who will be active in that place. Every prohibition contained in Sasi has a certain period of time, so that it benefits the environment. The benefits of Sasi Laut, for example, are to maintain the viability of fish in the bay. Sasi Field makes maximum yields, because they cannot be picked before the harvest period arrives.

Installation of Sasi is carried out at sea to protect natural resources in the sea of Southeast Maluku such as fish, lola, fishpond, fish eggs, seaweed and pearl breeding are important things done by the authority of the customary authorities because the community believes that the results of the natural resources of the sea have been reduced due to excessive consumption patterns of the local community so that when taking these natural resources in an irresponsible manner it is necessary to do Sasi to restore the stability of the natural conditions of the sea for the survival of the people who live mostly and depend on marine resources. Besides that, Sasi is also considered as a tradition or local wisdom that is very sacred so that it has become a habit in the social life of the community where when things happen that are not desirable, the traditional leader takes the action of pairs of Sasi which are first deliberated by the Adat council.

\subsection{Application of Hawear customary law in prevention of pollution and damage of natural resources and the environment around sea coast in southeast Maluku regency}

Talking about the active role of the community in environmental protection and management is regulated in Article 70 paragraph (1-3) of the Environmental Protection and Management Act, hereinafter referred to as UUPPLH. Article 70 paragraph 1 (1-3) of the UUPPLH states:

(1) The community has the same and broadest rights and opportunities to play an active role in environmental protection and management.

(2) The role of the community can be in the form of: (a) social supervision;

(b) giving suggestions, opinions, proposals, objections, complaints; and / or

(c) Submitting information and / or reports.

(1) The role of the community is done to:

(a) raising awareness in environmental protection and management;

(b) increase independence, community empowerment, and partnerships;

(c) fostering community capacity and leadership;

(d) fostering community responsiveness to conduct social supervision; and

(e) develop and maintain local culture and wisdom in the context of preserving environmental functions.

The active role of the community in the protection and management of the environment and natural resources naturally enters the customary law community, such as the customary law community of Hawear in Southeast Maluku Regency, both large and small Kei. Take for example in the Kei community to protect, private/ private or public ownership, then the ancestors (Teten Evav) have realized that protection into a sign or symbol that is recognized and obeyed by all Kei people. "The prohibited sign used in the form of young coconut leaves (yellow palm) which is cross-woven with coconut fronds, then tied to a stick stuck to the ground near the object or object to be seated, which in Kei language (Veve Evav) is called Hawear, which later became widely known as Hawear Balwirin "said Rahanubun.

Admittedly, past Evav communities still lived in groups in their respective groups with their own local laws, for example in the village of Laar Itel (now Elaar) there was local law Sasaktel, then Reli Badamas Village (now Matwair) with local law Kot Fit or local law Desa Dabraan, (Danar) with its local law Yetomat Balwirin. "Local law is highly respected, obeyed and upheld by local community groups in daily life, but over time, in the 14th century it met with Larvul Ngabal's legal agreement to be enforced throughout the Kei Islands, Hawear Balwirin was accepted by the indigenous people of Ur Siw Lor Lim, because Hawear Balwirin is an inseparable part of the Larvul Ngabal customary law [23].

The name Balwirin comes from Wirin Bal Romlob which is the name of Wirin in the village of Dabraan (now Danar). "Wirin is a coastal area that is overgrown with many coconut trees where, the surface layer is grayish black with a thickness of approximately $20 \mathrm{~cm}$, the rest is white sand". Young coconut leaves (janur yellow), which were first taken to make sasi (hawear), were taken from coconut trees that grow in the Bal Rumlob wirin, then at that time the Hawear was given the name Hawear Balwirin, not Hawear Balwarin as is often mentioned people all this time.

Gerson Rahanubun explained, Hawear Balwirin, had two functions, namely a criminal function, if two people who had large-scale clashes like the 1999 riots in Kei, then the peace was carried out in a traditional ceremony attended by Rat, Orang Kai, Soa, Saniri and parties the problem. "The Adat holders settled the dispute on a family basis, based on a peace agreement and mutual forgiveness between the two parties. The peace was held in a traditional ritual ceremony called Hawear Nam Sait, Ni Baran Nas or meaning Sasi was pulled in half, and arrows were sent / shot into the air.

While the civil function, to protect private or public property such as coconuts, Lola, sea cucumbers, etc. "If one of the villages wants the coconut to be satiated, then a village meeting is held first to determine the right time for Sasi and 
how long the Sasi is installed, Sasi is established in the open, so everyone can see it, the period of time Sasi is established until it opens Sasi called Yetut "Explained Rahanubun. (Neri Rahabav, Vox Populi Newspaper) [24].

The civilization of a nation is strongly influenced and determined by the local culture, as well as for the people in the Kei Islands (Nuhu Evav), the ancestral dictum past on the stage of real and natural daily life, namely Hira Ni Natub Fo This, It Did Natub Fo It Did the means to have someone still his, and ours are still ours. "Inwardly it contains recognition and appreciation, awareness, nobleness, prohibitions, borders, human rights and the law not to steal, rob, rob, manipulate, harass and deceive the property of others".

The four earliest advices are a summary of the criminal law called Nevnev's Law, and it is believed to be Larvul's Law, which was formulated at a meeting of the nine union melmeles in Elaar, Nuhu Roa. The next two tips are a summary of family law called Hanilit's Law, while the last advice is a summary of property law called Balearin's Hawear Law. Hanilit's Law and Hawear Balwirin's Law are believed to be Ngabal Laws which were formulated at the meeting of the five union-forming mel at Ler Ohoilim, Yūt [4].

Judging from the binding strength of the Hawear custom, the researchers hope that this Hawear custom is applied in preventing pollution and destruction of natural resources and the marine coastal environment in Southeast Maluku Regency, so that the environment remains beautiful on one side and on the other the environment can be enjoyed by future generations present and future generations. According to Indigenous Hawear researchers who apply to Indigenous Hawear communities in Southeast Maluku Regency, both large and small Kei, this is a principle of caution (early prevention) in the protection and management of the environment and the management of their natural resources so that they can be enjoyed by generations. them and future generation. Where the principle of prudence (early prevention) and the principle of sustainability are the main environmental legal principles in the protection and management of the environment on a regional, national and international scale.

According to researchers, the Hawear Customary Law in Kabupaen, Southeast Maluku, can be applied in preventing pollution and environmental damage and natural resource management on the coast of Southeast Maluku by conducting customary deliberations (which are followed by customary leaders (Adat elders). (Indigenous elders) held a meeting and formulated customary law norms whose meaning was expanded to apply to the prevention of environmental pollution and destruction and management of natural resources in coastal communities, so that the coastal coasts together with their marine biota could be enjoyed by the Hawear Indigenous Peoples in Kabupaen Southeast Maluku from the present generation and future generations in accordance with the principles of sustainability in the general explanation of the UUPPLH, so that the problems faced by the Hawear Indigenous people in the field of natural resource management and the environment in the Coastal communities especially coastal areas, the sea and small islands 1 Southeast Maluku Regency no more damage to coral reef ecosystems in Ohoi Ngurbloat Kei Kecil District, Southeast Maluku Regency. As is currently happening on the Ngurbloat coast based on criteria of abundance index values, and diversity indices expressed in damaged to moderate conditions this is due to anthropogenic (human activities) and non-anthropogenic (ecological changes, natural factors), including: fishing using fish bombs, arrowheads. nets and traps. Intake of coral for building materials and aquarium decoration and wall decoration.

To strengthen researchers' assumptions that Hawears can be applied to prevent pollution and damage to the management of natural resources and the environment on the sea coast in Southeast Maluku Regency, the researchers formulate norms, based on the theory of norm levels that have the right to formulate or make legal norms. law such as the Regional Representative Council (DPR), but according to the author there are formal legal institutions and non-formal legal institutions, customary institutions are informal legal money institutions but according to the authors of traditional law institutions their existence is very strong this can be seen in the recognition of the Republic of Indonesia about the validity of customary law contained in article $18 \mathrm{~B}$ paragraph (2) that the state recognizes the existence of customary law with three (3) requirements, namely (1) as long as there is, (2) based on the Law and (3) in the frame of the Unitary State of the Republic of Indonesia ( Homeland).

From the meaning above, according to the authors the institution can formulate customary norms meant to expand the formulation of Sasi norm (Hawear) which was originally only Sasi Lompa, Sasi woman, Sasi land, Sasi coconut, but Sasi can be expanded by expanding the formulation of Sasi norm (Hawear) namely Sasi towards 9) Environmental areas and natural resources) which are according to local customary institutions. Initially "Sasi (Hawear) as a sign of prohibition to protect people's property such as Sasi can also be used as a sign of prohibition that is used by other people by force, Hawear is also to protect the environment. Like Sasi meti, Sasi hamlet plants for a certain period of time to get a lot of results. The place that was seated was given the name Yot. The name of the village that was covered was marked with Hawear, the Hewear was to protect our goods from the disturbance of people. While in the protection and management of the marine coastal environment can be applied Hawear (Sasi) to prevent pollution and environmental damage to the coast of the sea in Southeast Maluku Regency.

In maintaining the formulation of these norms so that they are sustainable in the customary law community, the writer refers to the theory of legal effectiveness and legal basis, in the theory of legal effect the law that is made depends on the community or the environment in which the community lives and develops. Of course, in the coastal communities in the district of Maluku, the effectiveness of the applicable law depends on the customary community. Meanwhile, according to the theory of law enforcement, legal enforcement is influenced by three factors: Philosophy, Juridical and Sociological factors. The rule of law applies sociologically, if the rule is effective. That is, the rule applies because of the recognition of the community.

Based on the explanation above, it appears how complex the issue of legal effectiveness in Indonesian society, especially the Hawear Indigenous coastal community in Southeast Maluku Regency. Therefore, the legal norms of Sasi which are extended both written and unwritten really function, can always be returned to the three Kaida mentioned above.

\section{CONCLUSIONES}

This research found the answers namely; According to researchers, Hawear's customary law in Kabupaen, Southeast Maluku, can be applied in preventing pollution and 
environmental damage on the sea coast in Southeast Maluku Regency by conducting customary meetings (which are followed by customary leaders (customary elders). Customary leaders (customary elders) ) held a deliberation and formulated customary legal norms such as what will be applied to the prevention of pollution and environmental damage on the sea coast, so that the coast along with the marine biota is usually enjoyed by the Hawear Indigenous people in Southeast Maluku Regency of the North Maluku and present generations.

The norm of Sasi (Hawear) has expanded its meaning from the original meti Sasi, Sasi dusun of plants for a certain period of time to get a lot of results. The place that was seated was given the name Yot. The name of the village that was covered was marked with Hawear, the Hewear was to protect our goods from the disturbance of people. While in the protection and management of the marine coastal environment the Sasi (Hawear) law can be applied to prevent pollution and damage to the environment on the sea coast in Southeast Maluku Regency so that natural resources and the environment will return beautiful.

\section{REFERENCES}

[1] Uar, N.D., Murti, S.H., Hadisusanto, S. (2016). Kerusakan Lingkungan akibat aktivitas manusia pada ekosistem terumbu karang. Majalah Geografi Indonesia, 30(1): 88-96. https://doi.org/10.22146/mgi.15626

[2] Judge, Z, Marissa, N. (2008). Peranan Hukum Adat Sasi Laut dalam Melindungi Kelestarian Lingkungan di Desa Eti Kecamatan Seram Barat Kabupaten Seram Bagian Barat $6 / 1$ https://media.neliti.com/media/publications/18037-IDperanan-hukum-adat-sasi-laut-dalam-melindungikelestarian-lingkungan-di-desa-eti.pdf.

[3] Sumardjono, M.S.W. (1996). Pedoman Pembuatan Usulan Penelitian Sebuah Panduan Dasar. Jakarta: Gramedia Pustaka Utama. http://pustakamaya.lan.go.id/opac/detail-opac?id=2491.

[4] Andrianih, A. (2012). Efektivitas undang-undang no 1 tahun 1965 tentang pencegahan penyalahgunaan dan/atau penodaan agama terhadap kerukunan beragama. Skripsi thesis, Universitas Pembangunan Nasional Veteran Jakarta. http://repository.upnvj.ac.id/4213/

[5] Ali, A. (2009). Menguak Teori Hukum (Legal Theory) dan Teori Peradilan (Judicialprudence) Termasuk Interpretasi Undang-Undang (Legisprudence). Jakarta. Penerbit

Kencana. http://lib.ui.ac.id/detail.jsp?id=20292154.

[6] Masykuri. (2013). Efektivitas, Hukum Penerapan Undang-Undang Nomor 41 Tahun 1999 Tentang Kehutanan Terhadap Penebangan Liar (Illegal Logging) di Kabupaten Kolaka Utara Propinsi Sulawesi Tenggara. http://repository.unhas.ac.id/handle/123456789/6191.

[7] Soekanto, S. (1976). Beberapa Permasalahan Hukum Dalam Kerangka Pembangunan di Indonesia. Yayasan Penerbit Universitas Indonesia. https://ib.atmajaya.ac.id/default.aspx?tabID=52\&prang $=$ Soekanto $\% 2 \mathrm{C}+$ Soerjono

[8] Mohammad, J. (2013). Politik hukum pengakuan peradilan adat di provinsi papua pasca berlakunya undang-undang otonomi khusus. Doctor thesis, Universitas Brawijaya. Malang. http://repository.ub.ac.id/160828/.
[9] Marzuki, P.M. (2009). Penelitian hukum. Kencana Prenada Media Group, Jakarta, 211-213. http://lib.ui.ac.id/detail?id=20373484.

[10] Asshiddiqie, J., Safa'at, M.A. (2006). Teori Hans Kelsen tentang hukum. Mahkamah Konstitusi RI, Sekretariat Jenderal dan Kenpaniteraan. http://pustaka.pu.go.id/biblio/teori-hans-kelsen-tentanghukum/E7J46

[11] www.mpr.wasantara.net.id. Diakses pada tanggal 9 Maret 2020

[12] Novita, R.A., Prasetyo, A.B., Suparno, P. (2017). Efektivitas pelaksanaan undang-undang nomor 2 tahun 1960 tentang perjanjian bagi hasil tanah pertanian (tanah kering) di desa bringin, kecamatan bayan, kabupaten purworejo. Diponegoro Law Journal, 6(2): 1-12. https://ejournal3.undip.ac.id/index.php/dlr/article/view/ 16975.

[13] Theory Hutchinson, (2002). Researching and Writing in Law. Second edition, Thomas Lawbook Co., Australia, Sydney, Pyrmont, Harris Street. https://eprints.qut.edu.au/6601/.

[14] Dova, H.S., Yanzi, H., Nurmalisa, Y. (2016). Peranan tokoh adat dalam mempertahankan adat tunggu tubang pada masyarakat semendo. Jurnal Kultur Demokrasi, 4(5).

http://jurnal.fkip.unila.ac.id/index.php/JKD/article/view /11391.

[15] Undang-Undang No 12 Tahu 2011 tentang Pembentukan Peraturan Perundang-Undanagn, Bagian Teknik Penyusunan Naskah Akademik Pancangan UndangUndang, Rancanagan Peraturan Daerah Provinsi, Rancanagan Peraturan Daerah Kabupaten/Kota. https://ngada.org/uu12-2011lmp1.htm.

[16] Bujur, S., Salahue, S., Sanggup, B., Kabar, B. (1998). Kamus Bahasa Indonesia-Karo A-K. Pusat Pembinaan dan Pengembangan Bahasa, Jakarta. http://repositori.kemdikbud.go.id/id/eprint/2876.

[17] Muhammad, B. (1994). Asas-Asas Hukum Adat. Jakarta: Pradnya Paramitha. http://lib.ui.ac.id/detail?id=20215585.

[18] Bzn, B.T.H. (1983). Asas-asas dan Susunan Hukum Adat. Terjemahan, Jakarta, Pradnya Paramita. Universitas Indonesia. http://lib.ui.ac.id/detail?id=20105731\&lokasi=lokal

[19] Siahaan, N.H.T. (2004). Rio Declaration on Environment and Development. Library of Congress -- Jakarta Overseas https://catalogue.nla.gov.au/Record/3420591.

[20] Undang-Undang Nomor 32 Tahun 2009 Tentang Perlindungan dan Pengelolaan Lingkungan Hidup. https://www.walhi.or.id/wpcontent/uploads/2018/07/uu-32-tahun-2009-ttgPERLINDUNGAN-DAN-PENGELOLAANLINGKUNGAN-HIDUP.pdf.

[21] Pengertian Hukum Lingkungan Menurut Para Ahli, Modern dan Klasikhttps:/www.silontong.com/2018/05/09/pengertia n-hukum-lingkungan/\#, diakses tanggal 28 Maret 2020.

[22] Soekanto, S., Mamudji, S. (1985). Penelitian Hukum Normatif Suatu Tinjuan Singkat. Jakarta: CV. Rajawali Press.

https://books.google.com/books/about/Penelitian_huku m_normatif.html?hl=id\&id=_Y1GPAAACAAJ.

[23] Hukum Larvul Ngabal 
https://id.wikipedia.org/wiki/Hukum_Larvul_Ngabal https://simdos.unud.ac.id/uploads/file_penelitian_1_dir/ 46c397ce3a3b8e31dfdbbd6dc082bb02.pdf, diakses tangga 1 Aprl 2020.

[24] Koran Vox Populi Malra dan Kota Tual Menuju Maluku
Tenggara

Baru

http://tenggararaya.blogspot.com/2011/04/maknahawear-balwirin-yang-terkoyak.html, diakses tangga 1 Aprl 2020. 